\title{
Industrial By-Products for the Rehabilitation of Coal Mining-Affected Areas - a Novel Approach
}

\author{
Arkadiusz Bauerek ${ }^{1}$, Jean Diatta ${ }^{2}$, Łukasz Pierzchała ${ }^{1}$, Alicja Krzemień ${ }^{1}$, and Angelika \\ Więckol-Ryk ${ }^{1}$ \\ ${ }^{1}$ Central Mining Institute \\ ${ }^{2}$ Poznan University of Life Sciences
}

June 19, 2021

\begin{abstract}
The blends of coal combustion by-products (CCBs) with organic wastes (sewage sludge and spent mushroom compost) were investigated for elaboration of soil substitutes for land rehabilitation of coal mine affected areas. The study incudes four types four types of habitat with different water retention and fertility i.e.: dry and moderate fertility (A1-A3), mesic and low fertility (B1-B3), mesic and moderate fertility (C1-C3), humid and low fertility (D1-D3). Obtained results revealed that the amounts of macronutrients were sufficient for supporting plant growth i.e.: N (0.44-0.60 \%), P (0.13-021 \%), K (1.63-1.98 \%), Mg (1.01$1.38 \%)$, Ca (5.32-8.23\%), S (2.66-4.12\%), whereas the concentration of organic matter varied within the range $20.3-27.9 \%$. Phytotest using white mustard (Sinapis alba) seeds under laboratory conditions showed that the best results of sprouting i.e: 56 and $66 \%$ were obtained for D2 and D3, respectively. The values of $\mathrm{pH}$ (8.16-8.78) and electrical conductivity (5.28-6.73 $\mathrm{mS} \cdot \mathrm{cm}-1$ ) of tested soil substitutes were found to be the decisive factors limiting the germination process. The coefficients between the parameters of soil substitutes and the Sinapis alba sproutings have revealed negative correlation with electrical conductivity $(\mathrm{r}=-0.46)$. Additionally, tests with meadow vegetation gave promising opportunity for the use of soil substitutes in the process of land rehabilitation. The cover of the mesic and dry meadow vegetation reached 90\%. The Principal Component Analysis (PCA) has outlined that $\mathrm{pH}$, content of $\mathrm{P}$ and organic matter, are the most important factors that influence cover of meadow vegetation.
\end{abstract}

Industrial By-Products for the Rehabilitation of Coal Mining-Affected Areas - a Novel Approach Arkadiusz Bauerek ${ }^{1 \mathrm{a}}$, Jean Diatta ${ }^{2}$, Lukasz Pierzchała ${ }^{1 \mathrm{~b}}$ Alicja Krzemień $^{1 \mathrm{c}}$ and Angelika Więckol-Ryk ${ }^{1 \mathrm{c} *}$ 1 Central Mining Institute, ${ }^{\mathrm{a} D e p a r t m e n t}$ of Environment Monitoring, ${ }^{\mathrm{b}}$ Department of Water Protection; ${ }^{c}$ Department of Risk Assessment and Industrial Safety, Plac Gwarkow 1, 40-166 Katowice, Poland

2 Poznan University of Life Sciences, Department of Agricultural Chemistry and Environmental Biogeochemistry, Wojska Polskiego 71F, 60-625 Poznań, Poland;

* Correspondence: awieckol@gig.eu

\section{Abstract:}

The blends of coal combustion by-products (CCBs) with organic wastes (sewage sludge and spent mushroom compost) were investigated for elaboration of soil substitutes for land rehabilitation of coal mine affected areas. The study incudes four types four types of habitat with different water retention and fertility i.e.: dry and moderate fertility (A1-A3), mesic and low fertility (B1-B3), mesic and moderate fertility (C1-C3), humid and low fertility (D1-D3). 
Obtained results revealed that the amounts of macronutrients were sufficient for supporting plant growth i.e.: N (0.44-0.60 \%), P (0.13-021 \%), K (1.63-1.98 \%), Mg (1.01-1.38 \%), Ca (5.32-8.23 \%), S (2.66-4.12 $\%$ ), whereas the concentration of organic matter varied within the range 20.3-27.9\%. Phytotest using white mustard (Sinapis alba) seeds under laboratory conditions showed that the best results of sprouting i.e: 56 and $66 \%$ were obtained for $\mathrm{D} 2$ and D3, respectively. The values of $\mathrm{pH}(8.16-8.78)$ and electrical conductivity $\left(5.28-6.73 \mathrm{mS} \cdot \mathrm{cm}^{-1}\right)$ of tested soil substitutes were found to be the decisive factors limiting the germination process. The coefficients between the parameters of soil substitutes and theSinapis alba sproutings have revealed negative correlation with electrical conductivity $(\mathrm{r}=-0.46)$. Additionally, tests with meadow vegetation gave promising opportunity for the use of soil substitutes in the process of land rehabilitation. The cover of the mesic and dry meadow vegetation reached $90 \%$. The Principal Component Analysis (PCA) has outlined that $\mathrm{pH}$, content of $\mathrm{P}$ and organic matter, are the most important factors that influence cover of meadow vegetation.

Keywords: Coal mining by-products; Artificial soils; Spoil tips; Land rehabilitation; Germination

\section{INTRODUCTION}

Coal-fired power plants are responsible for producing millions of tons of coal combustion by-products (CCBs) including: fly and bottom ash, boiler slag, flotation waste or flue gas desulfurization material (Akcil \& Koldas, 2006.; Asik et al. , 2009; Bauerek et al., 2017.; Bian et al. , 2010).

The recycling of industrial by-products and wastes considered as "non valuable" materials is posing a challenge for environmental management. Only a small fraction of wastes generated from combustion of coal is applied to other technologies. The CCBs can be used as components in the production of cement, grout, blocks, lightweight aggregate, bricks or asphalt filler (Park et al. , 2014). Bottom ash and boiler slag can be used as both fine and coarse lightweight aggregates (Siddique, 2010). Fly ash, apart from construction materials, is also used in agriculture as an improver for degraded soil.

The scientific literature describes the application of fly ash materials for removing heavy metals from aqueous systems and improving the properties and quality of degraded soils (Cheng et al. , 2016; Dhindsa et al. , 2016; Park, 2014; Sajwan et al. , 2006). Fly ash is composed of over $20 \%$ of lime and for that reason it can also neutralize soil acidity to a level suitable for agricultural crops (Skousen et al. , 2013). Compared to the bottom ash, it displays better heavy metals inactivation in contaminated soil (Diatta et al. , 2016).

Another possibility of CCBs' use is underground mine backfilling together with rock waste, to avoid mine collapse in further and deeper extraction phases (Jiang et al. , 2017; Sheshpari, 2015; Skrzypkowski, 2018; Zhang et al. , 2019). Such applications of waste as a backfilling material limit mining damage and subsidence of the surface (Bian et al. , 2010; Skrzypkowski, 2018; Zhanget al. , 2019).

In the area of coal mining industry, the landfilled wastes generated in mining and quarrying industries amounted to 61,360,000 tones and constituted 53.2 \% of total Polish rock waste in 2018 (Statistic of Poland, 2019). A large majority of total mining wastes i.e. 36,900,000 tones $(60.1 \%)$ were disposed by landfilling, $24,100,000$ tones $(39.3 \%)$ processed and recovered by waste producers and merely 318 tones $(0.52 \%)$ have been temporarily stored and transformed by other recipients. According to Gawor (Gawor, 2014) in the Upper Silesian Coal Basin, there are 220 coal mining waste heaps with over 760 million tones of waste, covering over 4,000 ha. It is estimated that for each tone of coal exploited, there is approximately 0.4-0.5 tones of waste materials, which are deposited at waste heaps impacting and degrading the neighbouring areas as well as landscape.

Mining waste materials at spoil tips contain high concentrations of sulphur (S) and significant amounts of heavy metals such as arsenic (As), antimony $(\mathrm{Sb})$, cadmium $(\mathrm{Cd})$, lead $(\mathrm{Pb})$, mercury $(\mathrm{Hg})$ and nickel $(\mathrm{Ni})$, which are environmentally and biologically toxic elements both to human health and agriculture zones, when they are released (Klojzy-Kaczmarczyk et al. , 2016; Szczepanska \& Twardowska, 1999). Additionally, the low concentration of macronutrients i.e. nitrogen $(\mathrm{N})$, phosphorus $(\mathrm{P})$ and potassium $(\mathrm{P})$ and organic matter of the stored wastes prevents the spontaneous succession of vegetation (Kirbyet al. , 2010). Coupled with 
toxic level of heavy metals, which restrict plant growth, the reclamation of mine waste heaps presents a complex task, also through their salinity and acidity (Matsi \& Keramidas, 1999).

The problem of pollution in coal mine spoils is caused by acid rock drainage (ARD) responsible for the deterioration of surface and groundwaters, soil and biodiversity at mining areas (US Environmental Protection Agency, 1994). The ARD is generated when iron sulfides, (mainly pyrite - $\mathrm{Fe}_{2} \mathrm{~S}$ ), aggregated in rock waste materials is exposed to oxygen and water (Harries \& Ritchie, 1985; Rudisell et al. , 2001; Xenidis et al. , 2002; Gitariet al. , 2008). Although weathering of pyrite is the main factor for initiation the process, also further hydrolysis of $\mathrm{Fe}^{3+}, \mathrm{Al}^{3+}$ and $\mathrm{Mn}^{2+}$ ions plays the most important role for releasing $\mathrm{H}^{+}$ions (acidity) to an environment (Watzlaf et al. , 2004). Sulfuric acid and iron dissolved into the surface waters can change their color into brown-orange and reddish colors of the effluents (Figure 1).

Janina Mine waste heap in Libiąż $\left(50^{\circ} 05^{\prime} 03.5^{\prime \prime} \mathrm{N}, 19.18^{\prime} 18.7^{\prime \prime} \mathrm{E}\right)$ is one of the biggest dumping sites of this kind located in the Silesia region in Poland. It covers an area of about 80 hectares (partly reclaimed) and contains almost 10 million tons of wastes poor in carbonates and chemically unstable. The ARD processes are manifested in occurrence of highly acidic runoff water ( $\mathrm{pH}$ differ from 2.1 to 3.5) contaminated by metals: $\mathrm{Al}, \mathrm{As}, \mathrm{Cd}, \mathrm{Co}, \mathrm{Cu}, \mathrm{Fe}, \mathrm{Mn}, \mathrm{Ni}$ and $\mathrm{Zn}$ (Bauereket al. , 2017). Janina Mine spoil tip as a totally unfriendly place for any spontaneous plants, because of its chemically aggressiveness and water shortage, is a good "field laboratory" for assessing land rehabilitation techniques in-situ. The restoration of the Janina Mine waste heap is a complex action due to the intensive erosion on the slopes and the high acidic character of waste.

\section{FIGURE 1}

The rehabilitation of coal-affected areas requires among others the use of available amendments, fertilizers, and stabilization techniques. The reclamation techniques described in scientific reports were based on the application of lime (Novak et al. , 2018), composted manures (Dumitru et al. , 2016; Haering et al. , 2015), municipal biosolids such as sewage sludge (Sevilla-Perea et al. , 2014), fly ash (Dhindsa et al. , 2016 ;Skousen et al. , 2013; Ukwattage et al. , 2013), or their mixture (Brown et al. , 2003).

The basic purpose of this paper was to outline a novel approach in the use of wastes generated in coal mines and coal-fired power plants. Several blends of wastes were tested as soil substitutes for two different semi-natural plant communities, which high ability to deliver ecosystems services on coal affected area. The study has initiated the preliminary "ecosystem-services" concept, by exhibiting eco-friendly and suitability of elaborated soil substitutes for semi-natural meadow communities (Larondelle \& Haase, 2012).

\section{MATERIALS AND METHODS}

\subsection{Waste materials}

Environmental regulations are currently enforcing any recovery of substrates, by-products and substances considered as ,non valuable" wastes. The challenging matter still emerges when dealing with recycling industrial wastes (ashes, slags, aggregates etc.) to finite usable products for environmental reclamation, such as soil substitutes. The latter ones should exhibit soil structures and chemical parameters suitable for plant communities intended for planting in the reclamation process. Therefore eight, following by-products (potential components of soil substitutes) differing in chemical composition, consistency and structure were selected to further tests and experiments. The selected wastes are generated in coal mines, coal-fired power plants, agriculture industries, and residues from waste water plants (Table 1).

TABLE 1 Set of by-products / potential soil substitute components and expected functions

\begin{tabular}{|c|c|c|c|}
\hline Symbol & $\begin{array}{l}\text { By-product/soil } \\
\text { substitute component }\end{array}$ & Deliver & $\begin{array}{l}\text { Expected function in } \\
\text { soil substitute }\end{array}$ \\
\hline $\mathrm{CFA}$ & $\begin{array}{l}\text { Fly ash from coal } \\
\text { combustion }\end{array}$ & $\begin{array}{l}\text { Power Plant Jaworzno } \\
3\end{array}$ & Acidity buffering \\
\hline BFA & $\begin{array}{l}\text { Fly ash from plant } \\
\text { biomass combustion }\end{array}$ & $\begin{array}{l}\text { Power Plant Jaworzno } \\
2\end{array}$ & Acidity buffering \\
\hline
\end{tabular}




\begin{tabular}{|c|c|c|c|}
\hline Symbol & $\begin{array}{l}\text { By-product/soil } \\
\text { substitute component }\end{array}$ & Deliver & $\begin{array}{l}\text { Expected function in } \\
\text { soil substitute }\end{array}$ \\
\hline$\overline{\mathrm{DL}}$ & $\begin{array}{l}\text { Decarbonisation lime } \\
\text { from water softening } \\
\text { process }\end{array}$ & Power Plant Łaziska & $\begin{array}{l}\text { Acidity buffering and } \\
\text { water retention }\end{array}$ \\
\hline $\mathrm{AG}$ & $\begin{array}{l}\text { Aggregate }(0-2 \mathrm{~mm}) \text { from } \\
\text { mine waste processing }\end{array}$ & Sobieski Coal Mine & $\begin{array}{l}\mathrm{pH} \text { regulation, soil } \\
\text { substitute skeleton } \\
\text { building }\end{array}$ \\
\hline SL & $\begin{array}{l}\text { Sealing material from } \\
\text { coal processing }\end{array}$ & Sobieski Coal Mine & $\begin{array}{l}\text { Water retention and } \\
\text { organic carbon supply }\end{array}$ \\
\hline ES & $\begin{array}{l}\text { Energetic slag from } \\
\text { coal combustion }\end{array}$ & Power Plant Łaziska & $\begin{array}{l}\text { Soil substitute skeleton } \\
\text { building }\end{array}$ \\
\hline SWS & Sewage sludge & $\begin{array}{l}\text { Sewage Treatment } \\
\text { Plant in Chrzanów }\end{array}$ & $\begin{array}{l}\text { Macroelements and } \\
\text { organic carbon supply }\end{array}$ \\
\hline $\mathrm{SMC}$ & $\begin{array}{l}\text { Spent mushroom } \\
\text { compost }\end{array}$ & $\begin{array}{l}\text { Mushroom farm in } \\
\text { Kryry }\end{array}$ & $\begin{array}{l}\text { Organic carbon and } \\
\text { macronutrients supply. } \\
\text { Structural regulation of } \\
\text { soil substitutes }\end{array}$ \\
\hline
\end{tabular}

\subsection{Analysis of physical and chemical parameters of wastes and soil substitutes}

The content of dry matter (DM) in wastes and soil substitutes was determined by the gravimetric method by drying samples to constant weight at $105^{\circ} \mathrm{C}$. The amount of organic matter $(\mathrm{OM})$ in the samples was determined by measuring of the loss-on-ignition of dry matter at $550^{\circ} \mathrm{C}$. Total ash was assessed by incinerating the respective samples at $815^{\circ} \mathrm{C}$ followed by weighting the post-combustion residues.

The content of macronutrients, i.e. $\mathrm{Ca}, \mathrm{K}, \mathrm{Mg}, \mathrm{P}$ and $\mathrm{Na}$ were assayed by means of $\mathrm{X}$-ray fluorescence method with wavelength dispersion WDXRF (Rigaku ZSX Primus, Inc., Wilmington, USA). The content of trace metals, i.e. $\mathrm{Cd}, \mathrm{Cr}, \mathrm{Cu}, \mathrm{Ni}, \mathrm{Pb}$ and $\mathrm{Zn}$ were determined by inductively coupled plasma atomic emission spectroscopy method (ICP-OES) after sample digestion in aqua regia (Perkin Elmer Optima 5300, Perkin Elmer Inc., Waltham, MA. USA). The total content of sulphur was determined with infrared spectroscopy (IR) using a ELTRA CHS (Eltra GmbH, Haan, Germany) whereas the content of nitrogen by the Kjeldahl method.

The wastes and soil substitutes were assayed for $\mathrm{pH}$ and electrical conductivity (EC) were measured by photometric and conductometric methods, respectively in aqueous solutions at the ratio $1: 2.5(\mathrm{w} / \mathrm{v})$. A sum up of selected waste parameters was provided in Table 2.

TABLE 2 Physical and chemical characterization of wastes used for soil substitutes blends

\begin{tabular}{|c|c|c|c|c|c|c|c|c|c|}
\hline Symbol & Unit & Wastes & Wastes & Wastes & Wastes & Wastes & Wastes & Wastes & Wastes \\
\hline & & CFA & BFA & DL & AG & SL & SWS & SMC & ES \\
\hline $\mathrm{pH}$ & - & 12.0 & 13.1 & 9.6 & 7.6 & 8.0 & 7.5 & 7.1 & 9.8 \\
\hline $\mathrm{EC}$ & $\mathrm{mS} \cdot \mathrm{cm}^{-1}$ & 3.60 & 39.4 & 1.57 & 0.50 & 0.90 & 12.18 & 7.76 & 0.35 \\
\hline Dry matter & $\%$ & 100.0 & 99.7 & 50.8 & 90.1 & 72.6 & 16,6 & 34.7 & 77.6 \\
\hline Organic matter & & 3.28 & 0.52 & 7.02 & 15.9 & 35.6 & 64.33 & 60.4 & 4.38 \\
\hline Total ash & & 96.7 & 99.5 & 93.0 & 84.1 & 64.4 & 35.67 & 39.5 & 95.6 \\
\hline $\mathrm{Ca}$ & & 2.27 & 9.65 & 32.0 & 0.43 & 0.34 & 4.45 & 8.22 & 2.74 \\
\hline $\mathrm{N}$ & & $<0.15$ & $<0.15$ & 0.32 & 0.18 & 0.40 & 4.61 & 2.36 & $<0.15$ \\
\hline K & & 2.05 & 5.53 & 0.04 & 2.32 & 1.69 & 0.04 & 1.03 & 2.14 \\
\hline $\mathrm{Mg}$ & & 1.15 & 2.43 & 5.44 & 0.24 & 0.57 & 0.74 & 0.42 & 1.69 \\
\hline $\mathrm{P}$ & & 0.10 & 1.07 & 0.01 & 0.02 & 0.03 & 2.73 & 0.78 & 0.11 \\
\hline
\end{tabular}




\begin{tabular}{llllllllll}
\hline Symbol & Unit & Wastes & Wastes & Wastes & Wastes & Wastes & Wastes & Wastes & Wastes \\
\hline $\mathrm{Na}$ & & 1.22 & 0.75 & 0.01 & 0.09 & 0.08 & 0.10 & 0.13 & 0.32 \\
$\mathrm{~S}$ & 0.16 & 0.98 & 0.24 & 3.95 & 0.63 & 1.87 & 1.97 & 0.32 \\
$\mathrm{Cd}$ & $\mathrm{mg} \cdot \mathrm{kg}^{-1}$ & 1 & 9 & $<1$ & 4 & $<1$ & 29 & $<1$ & 1 \\
$\mathrm{Cr}$ & 88 & 54 & 1 & 22 & 76 & 74 & 7 & 53 \\
$\mathrm{Cu}$ & & 86 & 173 & 3 & 85 & 31 & 269 & 29 & 46 \\
$\mathrm{Ni}$ & 67 & 28 & 9 & 26 & 33 & 42 & 7 & 47 \\
$\mathrm{~Pb}$ & 94 & 176 & 4 & 213 & 53 & 300 & 2 & 3 \\
$\mathrm{Zn}$ & & 139 & 610 & 36 & 1281 & 141 & 2710 & 183 & 22 \\
\hline
\end{tabular}

\subsection{Soil substitutes blends}

Soil substitutes were prepared by appropriate blending of wastes (Table 3). The experiments were run at three operational stages, namely I, II and III. During the study four types of soil substitutes blends with different fertility and water retention ability were developed i.e. dry and moderate fertility (A), mesic and low fertility (B), mesic and moderate fertility (C), humid and low fertility (D). Soils substitutes blends (A1-D3) differed from each other in terms of the type of wastes and their percentage share $(n=36)$.

TABLE 3 List of wastes and their percentage range (wt.\%) within given soil substitutes blends

\begin{tabular}{llll}
\hline Wastes & SOIL SUBSTITUTES BLENDS & SOIL SUBSTITUTES BLENDS & SOIL SUBSTITUTES BLEN \\
\hline & A1-A3 (I) & B1-B3 (I) & C1-C3 (I) \\
CFA & $0-10$ & $5-15$ & $0-10$ \\
BFA & $0-5$ & $10-25$ & $0-5$ \\
DL & $10-15$ & $10-15$ & $10-15$ \\
AG & $25-40$ & $30-30$ & $25-40$ \\
SL & $10-15$ & $15-15$ & $10-15$ \\
ES & 0 & 0 & 0 \\
SWS & $20-20$ & $10-10$ & $20-20$ \\
SMC & $15-15$ & $15-20$ & $15-15$ \\
\hline
\end{tabular}

A1-A3, B1-B3, C1-C3, D1-D3 - soil substitutes dedicated to vegetation (I, II, III) - Consecutive stages for testing soil substitutes

Additionally garden soil (RG) and substrate for germination (RS) were used as two control soils for the germination tests in order to determine the growth potential of the soil substitutes. Control soils have been selected in order to represent different conditions like $\mathrm{pH}$, organic matter and $\mathrm{N}, \mathrm{P}, \mathrm{K}$ concentrations, more or less favorable for seeds germination (Table 4).

TABLE 4 Parameters of control soils used in germination tests

\begin{tabular}{lllllll}
\hline Symbol & $\begin{array}{l}\text { Experimental } \\
\text { Conditions }\end{array}$ & $\begin{array}{l}\text { Experimental } \\
\text { Conditions }\end{array}$ & $\begin{array}{l}\text { Experimental } \\
\text { Conditions }\end{array}$ & $\begin{array}{l}\text { Experimental } \\
\text { Conditions }\end{array}$ & $\begin{array}{l}\text { Experimental } \\
\text { Conditions }\end{array}$ & $\begin{array}{l}\text { Experimental } \\
\text { Conditions }\end{array}$ \\
\hline & $\mathbf{p H}$ & $\mathbf{E C ~} \mathbf{~ m S \cdot \mathbf { c m } ^ { - 1 }}$ & $\mathbf{O M ~ \%}$ & $\mathbf{N ~ \%}$ & $\mathbf{P}$ & $\mathbf{K}$ \\
& & & & & $\%$ & $\%$ \\
$\mathrm{RS}$ & 5.5 & 443 & 89.1 & 0.91 & 0.11 & 0.12 \\
$\mathrm{RG}$ & 8.3 & 215 & 4.1 & 0.29 & 0.22 & 0.66 \\
\hline
\end{tabular}

RS-substrate for germination, RG-garden soil, EC-electrical conductivity, OM-organic matter 
Each stage was completed with a germination phytotest using white mustard (Sinapis alba). Based on the data from the germination tests and the results of soil substitutes chemical analysis, the share of individual wastes in the consecutively elaborated soil substitutes has been corrected. The $\mathrm{pH}$ of soil substitutes and electrolytic conductivity (EC) expressed in the paper permutedly as salinity were found to be the decisive parameters limiting the germination process of white mustard.

On this basis, fly ash from biomass combustion (BFA) and sewage sludge (SWS), with conductivity 39.4 $\mathrm{mS} \cdot \mathrm{cm}^{-1}$ and $12.18 \mathrm{mS} \cdot \mathrm{cm}^{-1}$ respectively, were eliminated from the next blending process at the stage II. The lack of these ingredients was supplemented by increasing the share of spent mushroom compost (SMC) and aggregate (AG).

At the stage III of the preparation of soil-substitutes, coal combustion fly ash (CFA), with a conductivity of $3.6 \mathrm{mS} \cdot \mathrm{cm}^{-1}$ was eliminated from the blending process. Instead of CFA, the energetic slag (ES) was introduced as a material with low conductivity/salinity $\left(0.35 \mathrm{mS} \cdot \mathrm{cm}^{-1}\right)$, while improving the structure of elaborated soil substitutes.

The reasons for such blending process was to ensure some basic factors: optimal structure of the blends (loose and lumpy), appropriate chemical parameters (for instance $\mathrm{pH}$, hydrolytic conductivity) along with nutrients $(\mathrm{N}, \mathrm{P}, \mathrm{K}, \mathrm{Mg}$ ) and particularly organic matter (substances) for ensuring a sustainable reclamation of affected mining areas.

\subsection{Seed germination tests}

White mustard (Sinapis alba) was used as the typical plant for seed germination test to assess the suitability of each soil substitute for vegetation development.

Seed germination assays were carried out on plastic sprouting bowls that contain $1 \mathrm{~kg}$ of soil substitute (Figure 2). In each sprouting bowl 50 seeds of Sinapis alba were placed in equal distance at the depth of 1 $\mathrm{cm}$. The tests were performed in laboratory conditions under constant temperature $\left(22^{\circ} \mathrm{C}\right)$, humidity $(30-$ $40 \%)$ and controlled light. Each sprouting bowl was watered once a day $(50 \mathrm{ml} /$ day $)$ and exposed to white light for 12 hours a day. The sprouting rate was counted after 20 days.

\section{FIGURE 2}

2.5. Phytotests with meadow species At the stage III of the experiment, seeds of semi-natural meadow communities were additionally used. They are represented by plant species typical for meadow communities in Central Europe. Taking into consideration habitat condition on waste heaps slopes, the species with low (dry meadow) and middle soil moisture requirements (mesic meadow) were used. Then, $3 \mathrm{~g}$ of the mesic and dry meadow seed mixture were sown into four types of soil substitutes (1 kg in plastic sprouting bowls). The tests were performed in three repetitions $(\mathrm{n}=12)$ from 11 May to 26 June in outdoor conditions without artificial application of water and light. At the end of the tests, the percentage coverage of developed meadow vegetation was evaluated. 2.6. Statistical analysis The normal distribution of data was confirmed using the Shapiro-Wilk test. The relationship between the Sinapis alba germination and physical-chemical parameters of soil substitutes were analysed using Pearson's linear correlation coefficient with Statistica 12.0 (StatsSoft, Poland). Principal Component Analysis (PCA) was applied in order to determine conditions that influence the development of native meadow vegetation on soil substitutes. The analysis was performed by using the CANOCO package. Variables data were transformed using $\log (\mathrm{x}+1)$ prior to the analysis response (Lepš \& Šmilauer, 2000). 3. RESULTS 3.1. Characteristics of the investigated wastes The wide range of data illustrated in the Table 2 shows the heterogeneity of the wastes and their chemical composition. Among all investigated wastes, only CFA, BFA and AG were extremely low in water content (90-100\% of DM), with SL and ES containing $72.6 \%$ and $77.6 \%$ respectively, and DL $50.8 \%$. Only SWS and SMC had high moisture content and very low dry matter: $16.6 \%$ and $34.7 \%$, respectively. Organic matter is the key parameter which decides about the environmental and biological sustainability of soil substitutes. Among all investigated wastes, only three i.e., SL (35.6\%), SMC (63.9\%) and SWS (74.8\%) could be considered as rich in organic matter. The AG, with $15.9 \%$ organic matter, could be involved as a moderate source, but 
its physical and mineralogical composition may act as a strongly limiting factor. Organic and dry matter have decisive effect on the content of ash in the waste. It is generally observed that materials with high organic matter content may record low ash concentration and vice-versa. Therefore, in the development of soil substitutes, it is strongly recommended to pay special attention to the content of organic matter in the blends. The content of $\mathrm{Ca}$ and $\mathrm{S}$ in the wastes and their further occurrence in the ready-to-use soil substitutes are of prime importance for the remediation of waste heaps, where the latter and its compounds cause excessive acidity, contrary to calcium, the addition of which significantly increases the $\mathrm{pH}$ value. The highest content of Ca i.e., $32 \%$ was observed in DL as compared to SL and AG, containing 0.34 and 0.43 $\%$, respectively. The other wastes were not higher in Ca than $10 \%$. Three of eight investigated wastes exhibited S content of: 2.39, 2.53 and $3.95 \%$ for SWS, SMC and AG respectively, while the S content in remaining wastes did not exceed $1.0 \%$. The chemical forms of S in those wastes may affect their utility for incorporating in the development soil substitutes. The research proved that only SWS contained much more $\mathrm{N}(5.1 \%)$ compared to the other wastes, where the low $\mathrm{N}$ content varied in the range $0.15-0.4 \%$. It is worth mentioning that natural soil ecosystems are typically poor in nitrogen content, hence the developed soil substitutes should comply with this rule. Nevertheless, a slightly enhanced N level may be expected as a "starter" for boosting plant growth at the anthropogenic (artificial) ground. In terms of P concentrations, only three of the wastes recorded values higher than $1.0 \%$, two of them typically organic, i.e. SWS $(1.25 \%)$ and SMC (1.02\%), and one mineral BFA (1.07\%). It should be observed that, BFA was characterized by the highest K content (5.65 \%) while DL and SWS exhibited the lowest content of K, from 0.04 to $0.23 \%$, respectively. Interestingly, DL contained the highest $\mathrm{Mg}$ concentration, reaching even $5.44 \%$. The patterns of metals distributions among the wastes are quite similar, but disparate depending on the metal types (Table 2). Higher content of $\mathrm{Cu}$ was observed at ashes BFA (241 $\left.\mathrm{mg} \cdot \mathrm{kg}^{-1}\right)$ and CFA (219 $\left.\mathrm{mg} \cdot \mathrm{kg}^{-1}\right)$ as well as for the sewage sludge SWS $\left(129 \mathrm{mg} \cdot \mathrm{kg}^{-1}\right)$. As in the case of $\mathrm{Cu}$ and $\mathrm{Zn}$ was also found from moderately high concentrations for CFA (219.0 $\left.\mathrm{mg} \cdot \mathrm{kg}^{-1}\right)$ and SMC $\left(412.0 \mathrm{mg} \cdot \mathrm{kg}^{-1}\right)$ to very high levels for BFA (911.0) and AG (1055.0 mg. $\left.\mathrm{kg}^{-1}\right)$. Excessive content of $\mathrm{Zn}$ was observed only for SWS (1704.0 $\left.\mathrm{mg} \cdot \mathrm{kg}^{-1}\right)$. The very high and excessive $\mathrm{Zn}$ contents of these wastes may be a potential source of it in soil substitutes. According to the Polish regulations (Minister of Agriculture and Rural Development, 2008), the permissible content of pollutants in organic-mineral fertilizers must not exceed $\left(\mathrm{mg} \cdot \mathrm{kg}^{-1}\right.$ of $\left.\mathrm{DM}\right)$ : $100 \mathrm{for} \mathrm{Cr}, 5$ for $\mathrm{Cd}, 60$ for $\mathrm{Ni}$ and 140 for $\mathrm{Pb}$. The excessive concentrations of Cd were observed only for SWS $\left(29 \mathrm{mg} \cdot \mathrm{kg}^{-1}\right)$ and BFA $\left(9 \mathrm{mg} \cdot \mathrm{kg}^{-1}\right)$. On the other hand the content of $\mathrm{Ni}$ was lower than the Polish limit value only for two of all wastes such as DL $\left(9 \mathrm{mg} \cdot \mathrm{kg}^{-1}\right)$ and SMC $\left(7 \mathrm{mg} \cdot \mathrm{kg}^{-1}\right)$. The excessive values for Pb were noticed for BFA (176 $\left.\mathrm{mg} \cdot \mathrm{kg}^{-1}\right), \mathrm{AG}\left(213 \mathrm{mg} \cdot \mathrm{kg}^{-1}\right)$ and SWS $\left(300 \mathrm{mg} \cdot \mathrm{kg}^{-1}\right)$. The concentration of $\mathrm{Cr}$ in all studied wastes can be considered on acceptable level $\left(<100 \mathrm{mg} \cdot \mathrm{kg}^{-1}\right)$. 3.2. Impact of $\mathrm{pH}$ and electrical conductivity on the Sinapis albagermination

White mustard (Sinapis alba) is very sensitive to factors limiting growth and hence sprouting also has been selected for verifying the possible potential of the soil substitutes for vegetation support. The $\mathrm{pH}$ value and the electrical conductivity were considered as two primary parameters decisive for an optimal seed germination and further plant growth. As reported in Figure 3 and based on the general classification (Bruce \& Rayment, 1982; Hazelton \& Murphy, 2016), the pH of the soil substitutes showed three basic ranges moderately alkaline ( $\mathrm{pH} 8.0-8.4)$, strongly alkaline $(\mathrm{pH} 8.5-9.0)$ and very strongly alkaline $(\mathrm{pH}>9.0)$, which are beyond the highest $\mathrm{pH}$ level (i.e. 7.5) potentially tolerable by Sinapis alba. The highest $\mathrm{pH}$ values (8.3-9.6) were measured at the stage I, but results of the soil substitutes from stages II and III were in ranges 8.0-8.3 and 8.2-8.8 respectively.

The soil substitutes with low water storage capacity and moderate content of nutrients showed the best sprouting for A3 in stage III (26\%) compared with the A2 (12\%) and A1 (0\%). Soil substitutes with low water retention and low content of nutrients showed good germination for B3 at the stage III (52\%). The most promising soil substitute with moderate ability to water retention and low content of nutrients was C3 at stage II (46\%). Germination of white mustard in soil substitutes with moderate water retention and moderate content of nutrients showed good results at stages I and II i.e: 58 and $56 \%$ for D2, respectively and $66 \%$ for D3. 
Since white mustard is very sensitive to soil conditions and salinity, the results observed on the Figure 3 supported the hypothesis that salinity could be mostly responsible for the lack or weak sprouting process. Based on the response of white mustard, for EC, the value of $6.50 \mathrm{mS} \cdot \mathrm{cm}^{-1}$ could be considered as the threshold for plants highly sensitive to saline media. Hence, soil substitutes characterized by EC [?] 6.50 $\mathrm{mS}^{*} \mathrm{~cm}^{-1}$ should be giving successful germination. Phytotests with white mustard showed that the most promising results were obtained at the stage III. The sprouting in reference soils $90 \%$ for RG and $92 \%$ for RS confirms that quality seed were used and tests were carried out in proper conditions for white mustard development.

\section{FIGURE 3}

\subsection{Impact of physico-chemical parameters of soil substitutes on the Sinapis alba germination}

The relationships between parameters reported in Tables 5 and Figure 3 have shown various interactions. The increase of Ca concentration (5.32-8.23\%) in the soil substitutes has induced a decrease in S content (2.66-4.12\%), but simultaneously raised $\mathrm{pH}$ and EC. Therefore, it should be hypothesized that only S induced $\mathrm{pH}$ decrease and was not directly and solely responsible for the control of the salinity of soil substitutes. Chemically, calcium reacts with sulphate ion $\left(\mathrm{SO}_{4}{ }^{2-}\right)$ to form some compounds reducing the chemical reactivity of $\mathrm{SO}_{4}{ }^{2}$. The physical and chemical parameters of soil substitutes prepared at the stage III were presented in Table 5.

TABLE 5 Physical and chemical characteristics of soil substitutes at the stage III

\begin{tabular}{llllllllllllll}
\hline Parameter & Parameter & A1 & A2 & A3 & B1 & B2 & B3 & C1 & C2 & C3 & D1 & D2 & D3 \\
\hline $\mathrm{pH}$ & & 8.32 & 8.19 & 8.16 & 8.24 & 8.20 & 8.28 & 8.22 & 8.43 & 8.24 & 8.56 & 8.78 & 8.37 \\
$\mathrm{EC}$ & $\mathrm{mS} \cdot \mathrm{cm}^{-1}$ & 6.73 & 6.67 & 6.63 & 5.39 & 5.98 & 5.66 & 5.90 & 6.19 & 6.30 & 5.80 & 5.28 & 5.71 \\
$\mathrm{DM}$ & $\%$ & 63.4 & 61.2 & 60.3 & 63.0 & 59.9 & 61.7 & 57.4 & 57.9 & 58.1 & 60.4 & 62.7 & 66.1 \\
$\mathrm{OM}$ & & 23.7 & 22.2 & 23.1 & 22.6 & 23.0 & 20.3 & 22.7 & 24.6 & 22.5 & 24.6 & 26.2 & 27.9 \\
Total ash & & 76.3 & 77.8 & 77 & 77.4 & 77.1 & 79.7 & 77.3 & 75.5 & 77.5 & 75.4 & 73.8 & 72.1 \\
$\mathrm{Ca}$ & & 8.23 & 5.51 & 6.33 & 5.32 & 5.88 & 6.0 & 6.18 & 6.95 & 6.07 & 6.88 & 5.92 & 5.38 \\
$\mathrm{~N}$ & & 0.51 & 0.56 & 0.6 & 0.44 & 0.46 & 0.45 & 0.5 & 0.51 & 0.52 & 0.48 & 0.48 & 0.48 \\
$\mathrm{P}$ & 0.2 & 0.21 & 0.21 & 0.14 & 0.18 & 0.17 & 0.19 & 0.17 & 0.2 & 0.16 & 0.13 & 0.13 \\
$\mathrm{~K}$ & 1.63 & 1.96 & 1.86 & 1.86 & 1.86 & 1.98 & 1.88 & 1.79 & 1.9 & 1.71 & 1.69 & 1.74 \\
$\mathrm{Mg}$ & 1.38 & 1.02 & 1.11 & 1.01 & 1.08 & 1.09 & 1.08 & 1.26 & 1.09 & 1.22 & 1.19 & 1.13 \\
$\mathrm{~S}$ & & 2.66 & 3.28 & 3.46 & 3.69 & 3.41 & 4.12 & 3.32 & 3.18 & 3.56 & 3.61 & 3.21 & 3.41 \\
$\mathrm{Na}$ & & 0.19 & 0.2 & 0.22 & 0.19 & 0.19 & 0.19 & 0.19 & 0.18 & 0.18 & 0.17 & 0.17 & 0.16 \\
\hline
\end{tabular}

The dry matter (DM) varied from 57.4 to $66.1 \%$, implying that most of incorporated wastes were characterized by relatively low water content. The concentration of organic matter is within the range $20.3-27.9 \%$. The contents of $\mathrm{Ca}$ and $\mathrm{N}$ varied respectively from 5.32 to $8.23 \%$ and 0.44 to $0.60 \%$, whereas the concentrations of $\mathrm{K}, \mathrm{Mg}$ and $\mathrm{P}$ exhibited values indicating that these amounts may be sufficient for supporting plant growth and further green biomass production, i.e: $1.63-1.98 \%$ for $\mathrm{K}, 1.01-1.38 \%$ for $\mathrm{Mg}$, and $0.13-0.21 \%$ for P. It should be pointed out that the reported concentrations deal with the vegetation of the so-called natural ecosystems, since its biological requirements for nutrients is low.

According to the linear correlation, the coefficients between the physical and chemical parameters of soil substitutes and theSinapis alba sproutings (Sin_alb, \%) have revealed negative correlation with EC ( $\mathrm{r}=$ 0.46). Water content (W), OM, pH, EC and concentration of other main chemical elements in soil substitutes: $\mathrm{Ca}, \mathrm{N}, \mathrm{K}, \mathrm{Mg}, \mathrm{P}, \mathrm{S}$ and Na did not show correlation with Sinapis albagermination (Table 6) nor did the content of trace elements.

TABLE 6 Linear correlation between of physico-chemical parameters of soil substitutes and the Sinapis alba germination at the stage III 


\begin{tabular}{lllllll}
\hline Parameter & Parameter & Soil substitutes & Soil substitutes & Soil substitutes & Soil substitutes & Soil substit \\
\hline & & $\mathbf{p H}$ & $\mathbf{W}$ & $\mathbf{O M}$ & $\mathbf{C a}$ & $\mathbf{N}$ \\
& & & $\mathbf{\%}$ & $\mathbf{\%}$ & $\mathbf{\%}$ & -0.25 \\
$\mathbf{p H}$ & - & 1.00 & 0.06 & -0.35 & 0.47 & 0.52 \\
$\mathbf{W}$ & & 0.06 & 1.00 & -0.16 & 0.30 & 0.16 \\
$\mathbf{O M}$ & $\%$ & -0.35 & -0.16 & 1.00 & -0.40 & 0.04 \\
$\mathbf{C a}$ & $\%$ & 0.47 & 0.30 & -0.40 & 1.00 & -00 \\
$\mathbf{N}$ & $\%$ & -0.25 & 0.52 & 0.16 & 0.04 & -0.42 \\
$\mathbf{K}$ & $\%$ & -0.02 & -0.41 & -0.65 & 0.05 & -0.30 \\
$\mathbf{M g}$ & $\%$ & 0.51 & -0.14 & -0.69 & 0.68 & 0.11 \\
$\mathbf{P}$ & $\%$ & 0.06 & -0.25 & -0.72 & 0.25 & -0.19 \\
$\mathbf{S}$ & $\%$ & -0.49 & 0.02 & 0.28 & -0.56 & -0.17 \\
$\mathbf{N a}$ & $\%$ & 0.49 & -0.04 & -0.62 & 0.44 & -0.12 \\
$\mathbf{E C}$ & $\mathrm{mS} \cdot \mathrm{cm}^{-1}$ & -0.25 & -0.43 & -0.26 & 0.14 & -0.20 \\
GER & $\%$ & 0.12 & -0.05 & 0.32 & & \\
\hline
\end{tabular}

W-water content; GER - Sinapis alba germination

\subsection{Phytotests with meadow vegetation}

Based on the data gathered throughout phytotests with mesic and dry meadow, the results showed a promising opportunity for implementing the tested soil substitutes from stage III as trials at the coal mine affected areas such as Janina Mine waste heap in Libiąż (Figures 4 and 5).

FIGURE 4

\section{FIGURE 5}

These plants were less sensitive to the harmful effects induced by salinity which in case of white mustard significantly limited and even hampered the first sproutings as well as its further growth. Additionally, both the mesic and dry meadow plants belong to the dicotyledonous plants which may develop a dynamic green biomass production, intensifying the rhizosphere activity and finally increasing carbon dioxide assimilation. The number of species for the mesic meadow (Figure 5a) varies between 5 (for A1, B1, C2, C3, and D5) through 6 (for A2, B2, B3, C1 and D2) to finally the highest number of species, i.e. 7 for D1, which indicates biodiversity of development ecosystems. The vegetation cover, as a proof of ability to growth in new environments varied significantly, from 40 to $90 \%$.

The number of species for dry meadow (Figure 5b) fluctuated also in a large range, from 4 (A2, D3) through 5 (A1, B3, C1, C3, D1, D2) to 6 (A3, B2, C2), reaching even 8 for B1 (Figure 6). The coverage was much more disparate: from 30 to $90 \%$, whereas $30 \%$ applied to only a single case (D2).

PCA (Table 7) was performed for evaluating the influence of the physical and chemical parameters of the soil substitutes on the meadow vegetation development. The first ordination axis of the PCA model (axis 1) accounts for $65.2 \%$ of the total variation of vegetation. This axis has a positive correlation with content of $\mathrm{OM}(0.60)$ and a negative correlation with the concentration of $\mathrm{P}(-0.45)$. The cover of mesic meadow species (Flo_Mea, \%) and dry meadow species (Dry_Mea, \%) has a negative correlation with this axis. The second axis (axis 2) explains $19.5 \%$ of response variables variation and shows a gradient in soil $\mathrm{pH}$ values. This axis has a positive correlation with the cover of mesic meadow species and a negative correlation with dry meadow species cover. The graphical illustration of the PCA analysis was presented in Figure 6 .

TABLE 7 Parameters of control soils used in germination tests

\begin{tabular}{lllllll}
\hline Parameter & $\mathrm{pH}$ & $\mathrm{P}$ & $\mathrm{S}$ & $\mathrm{EC}$ & $\mathrm{Ca}$ & $\mathrm{OM}$ \\
\hline & - & $\%$ & $\%$ & $\mathrm{mS} \cdot \mathrm{cm}^{-1}$ & $\%$ & $\%$
\end{tabular}




\begin{tabular}{lllllll}
\hline Parameter & pH & P & S & EC & Ca & OM \\
\hline Axis 1 & $\mathbf{0 . 4 9}$ & $\mathbf{- 0 . 4 5}$ & 0.04 & -0.11 & -0.17 & $\mathbf{0 . 6 0}$ \\
Axis 2 & $\mathbf{0 . 4 5}$ & 0.08 & 0.24 & 0.07 & 0.23 & 0.05 \\
\hline
\end{tabular}

\section{FIGURE 6}

\section{Discussion}

Soil organic matter plays a major role in terrestrial ecosystems. The concentration of organic matter in developed soil substitutes is within the range $20.3-27.9 \%$, and these levels are highly satisfactory, particularly if we compare to natural soils with about 1 to $5 \%$ of total organic matter (Garratt et al., 2018). Organic materials maintains the soil structure, improves water infiltration, increases the water holding capacity and reduces the risk of soil erosion. In addition, its decomposition provides nutrients for plants (Krull et al. , 2009). The major components of soil organic matter are humic substances and fulvic acids. The results of (Asik et al. , 2009) and (Çeliket al. , 2010) studies have shown positive effects of the humic substances on seed germination, seedling growth, root initiation, root growth, shoot development and the uptake of macroand microelements. Soil humic substances may also mitigate abiotic stress conditions caused by unfavorable $\mathrm{pH}$, and high salinity. According to (Hazelton \& Murphy, 2016) the optimal pH range for a variety of plants is from 5 to 8 . Obtained data pf $\mathrm{pH}$ for soil substitutes was in range from 5.1 to 11.7. The results of EC varied within very large range, from 4.7 to $11.7 \mathrm{mS} \cdot \mathrm{cm}^{-1}$, which corresponds to two classifications (Miller \& Donahue, 1995): moderately saline in the range of 4 to $8 \mathrm{mS} \cdot \mathrm{cm}^{-1}$ (sprouting, biomass and yields of many plants are restricted) and strongly saline from 8 to $16 \mathrm{mS} \cdot \mathrm{cm}^{-1}$ (only tolerant plants develop satisfactory biomass and yields).

The primary macronutrients for plant growth and developments are N, P, K while the secondary are Ca, $\mathrm{Mg}$ and S. Nitrogen is responsible for biomass build up (Heaton et al. , 2004; Lee et al. , 2017), P for good development of plant root systems (Shen et al. , 2018; Wissuwa et al., 2005), K for internal water management in plants (Grzebisz et al. , 2013) and Mg for photosynthesic activity (Guoet al. , 2016; Hermans \& Verbruggen, 2005).

The organic matter content also increases P sorption capacity of the soil (Kang et al. , 2009), which could cause decreasing phosphorus availability for plants in the soil substitutes with higher organic matter contents. Phosphorus constitutes an essential element for seed germination, seedling establishment, and plant growth (John et al. , 2016; Malhotra et al. , 2018; Neitzke, 2002; Venterink \& Güsewell, 2010) at the same time affecting the variety of meadow species (van Dobben et al., 2017; Venterink \& Güsewell, 2010; Weigeltet al. , 2005). The species characteristic for mesic meadows have shown increasing coverage with higher $\mathrm{P}$ concentration, which proved its role in soil fertility and plant growth.

The $\mathrm{pH}$ of soil substitutes has shown significant influence on developing both semi-natural meadow communities, which renders it the major factor affecting habitat conditions for many meadow species (Venterink \& Güsewell, 2010). Soil substitutes for the establishment of semi-natural meadow communities were characterized by alkaline conditions ( $\mathrm{pH} 8.16-8.78$ ) and content of Ca between 5.23 to 8.23\%. Such calcareous conditions often exhibit a high concentration of bicarbonate in the soil solution and induce low availability of Fe and $\mathrm{Zn}$ (George et al. , 2011). On the other hand, high pH has shown a negative effect on developing dry meadow communities, contrarily to Ca manifesting positive effect on mesic meadow communities, and it could be associated with a decrease of negative influence of S. The habitats with high content of Ca are characteristic for the type of meadow communities that are considered as the richest and most endangered ecosystems of the natural environment of Europe (Boron et al. , 2019). Generally over the past few decades, a significant decrease in area of semi-natural meadow has been observed across the world (Tokarczyk, 2017). The semi-natural meadow vegetation are ecosystems with the ability to deliver ecosystem services such as: pollination, herbs for traditional medicinal use, nutrient cycling, nutrient and water retention, biomass production, recreation and climate regulation (Lamarque et al. , 2011; Villoslada Peciña et al. , 2019). Data from 
the current preliminary study have shown that using waste materials for the development of soil substitutes, which are eco-friendly and suitable for semi-natural meadow communities is possible. Further research is needed to evaluate long-term development of semi-natural meadow communities on such type of reclaimed coal-mine affected areas. The mining waste heaps seem to offer suitable area for these types of semi-natural communities development.

\section{Conclusions}

Using coal combustion by-products along with sewage sludge and spent mushroom compost allowed the elaboration of soil substitutes addressing land rehabilitation of coal mine affected areas. Sewage sludge and spent mushroom compost enrich soil substitutes with organic matter and valuable nutrients such as $\mathrm{N}, \mathrm{P}$ and $\mathrm{K}$.

The application of phytotests - white mustard, mesic meadow and dry meadow species - for evaluating the potential vegetation support, have revealed three key factors which controlled the eco-usefulness of the soil substitutes: $\mathrm{pH}$, electrical conductivity and organic matter content.

Stabilizing the $\mathrm{pH}$ to values around 8.0 was critical for neutralizing the excess of acidity at the reclamation site. Ground phytotests showed that soil substitutes with EC [?] $6.50 \mathrm{mS}^{*} \mathrm{~cm}^{-1}$ were the most promising for plant growth. This pattern should be complemented with $23 \%$ of OM as it is the most suitable for developing meadow vegetation. A higher concentration of OM (as ascertained by PCA) could negatively affect cover meadow vegetation.

Experimental data presented in the paper shows that eco-friendly characteristics of soil substitutes were reached. Ca and $\mathrm{N}$ levels varied respectively from 5.32 to $8.23 \%$ and 0.44 to $0.60 \%$, whereas $\mathrm{K}: 1.63-1.98$ \%, Mg: 1.01-1.38 \% and P: 0.13-0.21 \% exhibited values indicating sufficiency for supporting plant growth and further green biomass production.

The environmentally oriented recovery of industrial wastes as proceeded at the current study met the circular economy objectives.

Acknowledgments: This research was funded by the Research Fund for Coal and Steel (Grant Agreement No. 847205-RECOVERY-RFCS-2018 07/2019-06/2023) and the Polish Ministry of Science and Higher Education (Contract No. 847205 z 17.04.2019 5036/FBWiS/2019/2 z 17.12.2019) under the project RECOVERY "Recovery of degraded and transformed ecosystems in coal mining-affected areas.

\section{Conflict of Interest Statement:}

The authors declare no conflict of interest

\section{References}

Asik BB, Turan MA, Celik H, Katkat AV. 2009. Effects of Humic Substances on Plant Growth and Mineral Nutrients Uptake of Wheat (Triticum durum cv. Salihli) Under Conditions of Salinity. Asian Journal of Crop Science 1 : 87-95. DOI: 10.3923/ajcs.2009.87.95

Bauerek A, Bebek M, Frączek R, Paw K, Kasperkiewicz W. 2017. Variability of chemical composition of acidic runoff waters from an active spoil heap of mining wastes representing sediments of the cracow sandstone series of the upper silesian coal basin. Przeglad Geologiczny65 : 450-458

Bian Z, Inyang HI, Daniels JL, Otto F, Struthers S. 2010. Environmental issues from coal mining and their solutions. Mining Science and Technology 20 : 215-223. DOI: 10.1016/S1674-5264(09)60187-3

Boroń M, Ociepińska M, Żeber-Dzikowska I, Gworek B, Kondzielski I, Chmielewski J. 2019. Xerothermic pavements - a meadow biodiversity richness. Jaworzno case study. Environmental Protection and Natural Resources 30 : 29-34. DOI: 10.2478/oszn-2019-0014

Brown SL, Henry CL, Chaney R, Compton H, DeVolder PS. 2003. Using municipal biosolids in combination with other residuals to restore metal-contaminated mining areas. Plant and Soil 249 : 203-215. DOI: 


\subsection{3/A:1022558013310}

Bruce R., Rayment G. 1982. No Title. Analytical methods and interpretations used by the Agricultural Chemistry Branch for Soil and Land Use Surveys. Bulletin QB82004. Queensland Department of Primary Industries.: Brisbane.

Çelik H, Katkat AV, Aşik BB, Turan MA. 2010. Effects of humus on growth and nutrient uptake of maize under saline and calcareous soil conditions. Žemdirbyste $=$ Agriculture 97 : 15-22

Cheng CM, Amaya M, Butalia T, Baker R, Walker HW, Massey-Norton J, Wolfe W. 2016. Short-term influence of coal mine reclamation using coal combustion residues on groundwater quality. Science of the Total Environment 571 : 834-854. DOI: 10.1016/j.scitotenv.2016.07.061

Dhindsa HS, Sharma RD, Kumar R. 2016. Role of fly ash in improving soil physical properties and yield of wheat (Triticum aestivum ). Agricultural Science Digest - A Research Journal 36 . DOI: 10.18805/asd.v36i2.10626

Diatta J, Fojcik E, Drobek L, Spizewski T, Krzesiński W. 2016. Assessment of Heavy Metals Inactivation in Contaminated Soil by Coal Fly and Bottom Ashes. Mineralogia 48 : 127-143. DOI: 10.1515/mipo-2017-0016

Dumıtru M, Cărăbış D, Pârvan L, Sârbu C. 2016. Environmental Rehabilitation of Mining Dumps. Agriculture and Agricultural Science Procedia 10 : 3-9. DOI: 10.1016/j.aaspro.2016.09.002

Gawor Ł. 2014. Coal mining waste dumps as secondary deposits - examples from the Upper Silesian Coal Basin and the Lublin Coal Basin.Geology, Geophysics \&6 Environment 40 : 285. DOI: 10.7494/geol.2014.40.3.285

George E, Horst WJ, Neumann E. 2011. Adaptation of Plants to Adverse Chemical Soil Conditions . Marschner's Mineral Nutrition of Higher Plants: Third Edition. Chapter 17. Elsevier Ltd. DOI: 10.1016/B978-0-12-384905-2.00017-0

Gitari WM, Petrik LF, Etchebers O, Key DL, Iwuoha E, Okujeni C. 2008. Passive neutralisation of acid mine drainage by fly ash and its derivatives: A column leaching study. Fuel 87 : 1637-1650. DOI: 10.1016/j.fuel.2007.08.025

Grzebisz W, Gransee A, Szczepaniak W, Diatta J. 2013. The effects of potassium fertilization on water-use efficiency in crop plants. Journal of Plant Nutrition and Soil Science 176 : 355-374. DOI: 10.1002/jpln.201200287

Guo W, Nazim H, Liang Z, Yang D. 2016. Magnesium deficiency in plants: An urgent problem. Crop Journal 4 : 83-91. DOI: 10.1016/j.cj.2015.11.003

Haering KC, Lee Daniels W, Feagley SE. 2015. Reclaiming Mined Lands with Biosolids, Manures, and Papermill Sludges. 615-644. DOI: 10.2134/agronmonogr41.c24

Harries JR, Ritchie AIM. 1985. Pore gas composition in waste rock dumps undergoing pyritic oxidation. Soil Science 140 : 143-152

Hazelton P, Murphy B. 2016. Interpreting soil test results. What do all the numbers mean? 3 rd Edition . CSIRO Publishing. DOI: 10.1111/sum.12402

Heaton E, Voigt T, Long SP. 2004. A quantitative review comparing the yields of two candidate C4 perennial biomass crops in relation to nitrogen, temperature and water. Biomass and Bioenergy 27 : 21-30. DOI: 10.1016/j.biombioe.2003.10.005

Hermans C, Verbruggen N. 2005. Physiological characterization of Mg deficiency in Arabidopsis thaliana. Journal of Experimental Botany 56 : 2153-2161. DOI: 10.1093/jxb/eri215

Jiang N, Zhao J, Sun X, Bai L, Wang C. 2017. Use of fly-ash slurry in backfill grouting in coal mines. Heliyon 3 : e00470. DOI: 10.1016/j.heliyon.2017.e00470 
John H, Dullau S, Baasch A, Tischew S. 2016. Re-introduction of target species into degraded lowland hay meadows: How to manage the crucial first year? Ecological Engineering 86 : 223-230. DOI: 10.1016/j.ecoleng.2015.11.001

Kang J, Hesterberg D, Osmond DL. 2009. Soil Organic Matter Effects on Phosphorus Sorption: A Path Analysis. Soil Science Society of America Journal 73 : 360-366. DOI: 10.2136/sssaj2008.0113

Kirby BM, Vengadajellum CJ, Burton SG, Cowan DA. 2010. Coal, Coal Mines and Spoil Heaps. In: Timmis K.N. (eds) Handbook of Hydrocarbon and Lipid Microbiology. Springer: Berlin

Klojzy-Kaczmarczyk B, Mazurek J, Staszczak J. 2016. Analysis of the quality of waste from coal mining in relation to the requirements for inter mining waste. Mineral Resources Management 95 : 227-242

Krull ES, Skjemstad JO, Baldock J a. 2009. Functions of Soil Organic Matter and the Effect on Soil Properties. GRDC Final Report CSO 00029 Residue Management, Soil Organic Carbon and Crop Performance $1-128$

Lamarque P, Tappeiner U, Turner C, Steinbacher M, Bardgett RD, Szukics U, Schermer M, Lavorel S. 2011. Stakeholder perceptions of grassland ecosystem services in relation to knowledge on soil fertility and biodiversity. Regional Environmental Change 11 : 791-804. DOI: 10.1007/s10113-011-0214-0

Larondelle N, Haase D. 2012. Valuing post-mining landscapes using an ecosystem services approach - An example from Germany. Ecological Indicators 18 : 567-574. DOI: 10.1016/j.ecolind.2012.01.008

Lee MS, Wycislo A, Guo J, Lee DK, Voigt T. 2017. Nitrogen fertilization effects on biomass production and yield components of miscanthus $\times$ giganteus. Frontiers in Plant Science 8 : 1-9. DOI: 10.3389/fpls.2017.00544

Lepš J, Šmilauer P. 2000. Multivariate analysis of ecological data [Mnohorozměrná analýza ekologických dat.]. - Biologická fakulta Jihočeské univerzity v Českých Budějovicích. České Budějovice

Malhotra H, Sharma S, Pandey R. 2018. Phosphorus Nutrition: Plant Growth in Response to Deficiency and Excess. Plant Nutrients and Abiotic Stress Tolerance. Chapter 7 , 1-590. DOI: 10.1007/978-981-10-9044-8

Matsi T, Keramidas VZ. 1999. Fly ash application on two acid soils and its effect on soil salinity, pH, B, $\mathrm{P}$ and on ryegrass growth and composition. Environmental Pollution 104 : 107-112. DOI: 10.1016/S02697491(98)00145-6

Miller R., Donahue R. 1995. Soils in our Environment: An Introduction to Soils and Plant Growth. 7th Revised edition. Prentice-Hall

Minister of Agriculture and Rural Development. 2008. Regulation of 18 June 2008 on the implementation of certain provisions of fertilizers and fertilization. Journal of Law [in Polish]

Neitzke M. 2002. Changes in energy fixation and efficiency of energy capture in above-ground biomass along an environmental gradient in calcareous grasslands. Flora 197 : 103-117. DOI: 10.1078/0367-2530-00020

Novak JM, Ippolito JA, Ducey TF, Watts DW, Spokas KA, Trippe KM, Sigua GC, Johnson MG. 2018. Remediation of an acidic mine spoil: Miscanthus biochar and lime amendment affects metal availability, plant growth, and soil enzyme activity. Chemosphere 205 : 709-718. DOI: 10.1016/j.chemosphere.2018.04.107

Park JH, Edraki M, Mulligan D, Jang HS. 2014. The application of coal combustion by-products in mine site rehabilitation. Journal of Cleaner Production 84 : 761-772. DOI: 10.1016/j.jclepro.2014.01.049

Park JY. 2014. The evolution of waste into a resource: Examining innovation in technologies reusing coal combustion by-products using patent data. Research Policy 43 : 1816-1826. DOI: 10.1016/j.respol.2014.06.002

Rudisell MT, Stuart BJ, Novak G, Payne H, Togni CS. 2001. Use of flue gas desulfurization by-product for mine sealing and abatement of acid mine drainage. Fuel 80 : 837-843. DOI: 10.1016/S0016-2361(00)00157-5 
Sajwan KS, Twardowska I, Punshon T, Alva AK. 2006. Coal Combustion Byproducts and Environmental Issues. New York, USA. DOI: DOI:10.1007/0-387-32177-2

Sevilla-Perea A, Almendros G, Mingorance MD. 2014. Quadratic response models for N and P mineralization in domestic sewage sludge for mininig dump reclamation. Applied Soil Ecology 75 : 106-115. DOI: 10.1016/j.apsoil.2013.10.007

Shen Q, Wen Z, Dong Y, Li H, Miao Y, Shen J. 2018. The responses of root morphology and phosphorusmobilizing exudations in wheat to increasing shoot phosphorus concentration. AoB PLANTS 10 : 1-11. DOI: 10.1093/aobpla/ply054

Sheshpari M. 2015. A review of underground mine backfilling methods with emphasis on cemented paste backfill. Electronic Journal of Geotechnical Engineering 20 : 5183-5208

Siddique R. 2010. Utilization of coal combustion by-products in sustainable construction materials. Resources, Conservation and Recycling 54 : 1060-1066. DOI: 10.1016/j.resconrec.2010.06.011

Skousen J, Yang JE, Lee JS, Ziemkiewicz P. 2013. Review of fly ash as a soil amendment. Geosystem Engineering 16 : 249-256. DOI: 10.1080/12269328.2013.832403

Skrzypkowski K. 2018. Compressibility of materials and backfilling mixtures with addition of solid wastes from flue-gas treatment and fly ashes. E3S Web of Conferences 71 : 3-8. DOI: 10.1051/e3sconf/20187100007

Statistic of Poland. 2019. Evironment 2019. 33th Edition. Warsaw

Szczepanska J, Twardowska I. 1999. Distribution and environmental impact of coal-mining wastes in Upper Silesia, Poland. Environmental Geology 38 : 249-258. DOI: 10.1007/s002540050422

Tokarczyk N. 2017. Forest encroachment on temperate mountain meadows - Scale, drivers, and current research directions. Geographia Polonica 90 : 463-480. DOI: 10.7163/GPol.0112

Ukwattage NL, Ranjith PG, Bouazza M. 2013. The use of coal combustion fly ash as a soil amendment in agricultural lands (with comments on its potential to improve food security and sequester carbon). Fuel109 : 400-408. DOI: 10.1016/j.fuel.2013.02.016

US Environmental Protection Agency. 1994. Acid Mine Drainage Prediction. U.S Environmental Protective Agency 52

van Dobben HF, Wamelink GWW, Slim PA, Kamiński J, Piórkowski H. 2017. Species-rich grassland can persist under nitrogen-rich but phosphorus-limited conditions. Plant and Soil 411 : 451-466. DOI: $10.1007 / \mathrm{s} 11104-016-3021-\mathrm{z}$

Venterink HO, Güsewell S. 2010. Competitive interactions between two meadow grasses under nitrogen and phosphorus limitation.Functional Ecology 24 : 877-886. DOI: 10.1111/j.1365-2435.2010.01692.x

Villoslada Peciña M, Ward RD, Bunce RGH, Sepp K, Kuusemets V, Luuk O. 2019. Country-scale mapping of ecosystem services provided by semi-natural grasslands. Science of the Total Environment661 : 212-225. DOI: $10.1016 /$ j.scitotenv.2019.01.174

Watzlaf G., Schroeder K., Kleinmann RL., Kairies C., Nairn R. 2004.Passive treatment of coal mine drainage . US. DOE/NETL-2004/1202

Weigelt A, Bol R, Bardgett RD. 2005. Preferential uptake of soil nitrogen forms by grassland plant species. Oecologia142 : 627-635. DOI: 10.1007/s00442-004-1765-2

Wissuwa M, Gamat G, Ismail AM. 2005. Is root growth under phosphorus deficiency affected by source or sink limitations? Journal of Experimental Botany 56 : 1943-1950. DOI: 10.1093/jxb/eri189

Xenidis A, Mylona E, Paspaliaris I. 2002. Potential use of lignite fly ash for the control of acid generation from sulphidic wastes. Waste Management 22 : 631-641. DOI: 10.1016/S0956-053X(01)00053-8 
Zhang J, Li M, Taheri A, Zhang W, Wu Z, Song W. 2019. Properties and application of backfill materials in coal mines in China.Minerals 9 . DOI: 10.3390/min9010053

\section{Hosted file}

FIGURE 1.docx available at https://authorea.com/users/420600/articles/526915-industrial-byproducts-for-the-rehabilitation-of-coal-mining-affected-areas-a-novel-approach

\section{Hosted file}

FIGURE 2.docx available at https://authorea.com/users/420600/articles/526915-industrial-byproducts-for-the-rehabilitation-of-coal-mining-affected-areas-a-novel-approach

\section{Hosted file}

FIGURE 3.docx available at https://authorea.com/users/420600/articles/526915-industrial-byproducts-for-the-rehabilitation-of-coal-mining-affected-areas-a-novel-approach

\section{Hosted file}

FIGURE 4.docx available at https://authorea.com/users/420600/articles/526915-industrial-byproducts-for-the-rehabilitation-of-coal-mining-affected-areas-a-novel-approach

\section{Hosted file}

FIGURE 5.docx available at https://authorea.com/users/420600/articles/526915-industrial-byproducts-for-the-rehabilitation-of-coal-mining-affected-areas-a-novel-approach

\section{Hosted file}

FIGURE 6.docx available at https://authorea.com/users/420600/articles/526915-industrial-byproducts-for-the-rehabilitation-of-coal-mining-affected-areas-a-novel-approach 